\title{
Analisis Kepemimpinan Kepala Desa Dalam Pengelolaan Desa (Studi Kasus Kampung Berumbung Baru Kecamatan Dayun Kabupaten Siak Provinsi Riau
}

\author{
Oleh : \\ MUAMMAR ALKADAFI \\ Email : alkadafi.amar@gmail.com \\ SAFIAH \\ DEVI DESWIMAR
}

\begin{abstract}
Abstrak
Pengelolaan desa sebagaiaman yang diatur dalam ketentuan Undang-Undang Nomor 6 Tahun 2014 Tentang Desa dalam implementasinya tidak terlepas dari aspek kepemimpinan desa itu sendiri. Kepemimpinan Desa/Kampung Berumbung Baru dalam Pengelolaan Kampung dapat menghantarkan Keberhasilan Kampung Berumbung Baru dalam penyelenggaraan pemerintahan, pelaksanaan pembangunan, pembinaan kemasyarakatan dan pemberdayaan masyarakat. Tujuan penelitian ini untuk mengetahui tipe kepemimpinan kampung berumbung baru dalam pelaksanaan kewenangan lokal berskala desa/kampung, musyawarah desa/kampung dan gerakan usaha ekonomi desa/kampung. Hasil penelitian dapat disimpulkan bahwa kepemimpinan Kepala Penghulu Kampung Berumbung Baru dalam pengelolaan Kampung dapat dikatakan berhasil mewujudkan desa/kampung yang maju dan mandiri sesuai dengan tujuan otonomi desa, tipe Kepemimpinan yang inovatif-progresif diterapkan oleh kepala penghulu kampung, baik dalam kepemimpinan pelaksanaan kewenangan lokal berskala desa/kampung, kepemimpinan dalam musyawarah desa/kampung sebagai mekanisme dalam pengambilan keputusan, dimana dalam musyawarah-musyawarah yang dilaksanakan mengedepankan aspek partisipasi masyarakat, demokratis, transparansi dan akuntabilitas. Begitu juga halnya, dengan Kepemimpinan Kepala Penghulu Kampung Berumbung Baru dalam usaha gerakan ekonomi desa/kampung terlihat dari pengelolaan aset-aset desa/kampung, pendirian dan pengelolaan Badan Usaha Milik desa/Kampung yang di kelola dengan baik dan memberikan kontribusi terhadap pergerakan ekonomi masyarakat dan berkontribusi terhadap pendapat asli desa/kampung.
\end{abstract}

Kata Kunci: Tipe Kepemimpinan, Kepala Desa, Pengelolaan Desa
Village Chief Leadership Analysis in Village Management (Case Study of New Berumbung Village, Dayun District, Siak Regency, Riau Province

\begin{abstract}
Village management as stipulated in the provisions of Law Number 6 of 2014 concerning Villages in its implementation cannot be separated from the aspects of
\end{abstract}


village leadership itself. New Village / Village Leadership in Village Management can deliver the success of New Village in the administration of government, implementation of development, community development and community empowerment. The purpose of this study was to determine the new type of village leadership in the implementation of local authority at the village / village level, village / village meetings and village / village economic business movements. The results of the study can be concluded that the leadership of the Head of Kampung Berumbung Baru Head in the management of the village can be said to succeed in creating an independent and independent village / village in accordance with the objectives of village autonomy, the type of innovative-progressive leadership applied by the head of the village head, both in the leadership of the implementation of local scale authority village / village, leadership in village / village meetings as a mechanism for decision making, where in the deliberations carried out prioritizing aspects of community participation, democracy, transparency and accountability. Likewise, the Head of Kampung Berumbung Baru's Head of Leadership in the village / village economic movement is seen from the management of village / village assets, the establishment and management of village / villageowned enterprises that are well managed and contribute to the economic movement of the community and contribute to the original opinion of the village / village.

Keywords : Leadership Type, Village Head, Village Management

\section{Pendahuluan}

Kebijakan nasional tentang pembangunan desa terus mengalami perubahan dan perkembangan, hal itu seiring dengan silih berganitinya pemerintahan (kepemimpinan nasional), sebagai wujud keberpihakan pemerintah untuk memperkuat kedudukan desa sebagai wilayah otonom, pemerintah mengeluarkan Undang -Undang Nomor 06 Tahun 2014 tentang Desa. Adapun ruang lingkup pengelolaan desa dalam ketentuan Undang-Undang Nomor 6 Tahun 2014 Tentang Desa meliputi Penyelenggaraan Pemerintahan Desa, Pelaksanaan Pembangunan, Pembinaan Kemasyarakatan dan Pemberdayaan Masyarakat.

Undang-Undang Nomor 6 Tahun 2014 Tentang Desa merubah paradigma dan konsep baru kebijakan tata kelola desa secara nasional. Paradigma Baru mengenai Desa tersebut juga sejalan dengan peran kepala Desa dalam memimpin Desa di era pembaharuan Desa seperti sekarang ini. Penjelasan UU nomor 6 tahun 2014 menyatakan Kepala Desa/Desa Adat atau yang disebut dengan nama lain mempunyai peran penting dalam kedudukannya sebagai kepanjangan tangan negara yang dekat dengan masyarakat dan sebagai pemimpin masyarakat.( Mustakim, 2015:11)

Kepemimpinan kepala desa merupakan variabel utama untuk mencapai keberhasilan desa melaksanakan kewenangan yang telah diberikan oleh UndangUndang. Kewenangan desa sebagaimana diatur dalam undang-undang ialah kewenangan berdasarkan hak asal-usul dan kewenangan lokal berskala desa. 
Kewenangan lokal berskala desa mencakup kewenangan dalam bidang penyelenggaraan pemerintahan, pelaksanaan pembangunan, pembinaan kemasyarakatan, pemberdayaan masyarakat.(Silahuddin,2015:22) Salah satu aspek penting dalam kewenangan desa ialah peranan kepala desa dalam melaksanakan pembangunan di desanya. Pembangunan desa merupakan proses untuk meningkatkan taraf hidup masyarakat melalui perbaikan seluruh aspek kehidupan masyarakat desa. Faktor yang sangat penting dalam proses pembangunan desa adalah peranan pemerintah dan partisipasi masyarakat desa dalam program pembangunan.

Permasalahan pelaksanaan pembangunan desa selama ini, dalam berbagai program telah dijalankan sejak pemerintahan orde lama hingga pemerintahan era reformasi. Fenomena dilapangan menunjukkan ada desa yang gagal melaksanakan program - program pembangunan, dimanan ketika program tersebut berakhir maka keluaran program tersebut sudah tidak berfungsi atau tidak terpelihara dan dilestarikan oleh masyarakat. Namun disisi lain ada juga desa yang mampu dan dikategorikan berhasil menjalankan program-program pembangunan desa yang telah dikeluarkan oleh pemerintah.

Salah satu desa yang ada di Provinsi Riau yang dikategorikan berhasil dalam melaksanakan pembangunan desa menjadi desa yang mandiri ialah desa Berumbung yang terletak di Kecamatan Dayun Kabupaten Siak. desa Berumbung mempunyai jumlah penduduk 1.962 jiwa tercatat desa punya banyak prestasi dalam bidang pembangunan. Desa ini pada tahun 2015 berhasil menjadi juara 1 lomba desa tingkat Kabupaten, Provinsi dan Tingkat Nasional, dan mendapat penghargaan dari Pemerintah Republik Indonesia. Adapun keunggulan desa Berumbung berdasarkan data awal yang penulis peroleh sehingga desa tersebut dikategorikan sebagai desa yang berhasil melaksanakan pembangunan, dan menjadi desa percontohan di Provinsi Riau yang mandiri ialah desa Berumbung berhasil menggali potensi desa dalam meningkatkan Pendapatan Asli Desa (PADesa) yang bersumber dari Partiispasi Masyarakat melalui Swadaya dan Gotong Royong, Sistem Pelayanan Pemerintahan Desa Berbasis Teknologi Informasi, Kelembagaan Sosial Ekonomi (Koperasi dan BUMDes), Badan Usaha Milik Desa saat ini telah berkembang dan memiliki aset mencapai 3,5 Milyar.( Dinas Komunikasi, Informatika, Dan Statistik Provinsi Riau 2015) Pelayanan Fasilitas Ambulans Gratis untuk masyarakat, produksi pupuk limbah padat dari bahan dasar limbah kotoran sapi hingga mencapai 60 ton pertahun yang dikelola masyarakat Kelompok Tani Makmur Jaya.(Rizkita, 2015. Media online kadesa.id). Dan Koperasi Konsumen Terbaik Nasional 2014. Desa Berumbung Baru memiliki sebuah Koperasi Unit Desa (KUD) yang sehat dengan bidang usaha bervariasi, yang dinamakan KUD Karya Maju. Pada tahun 2014, KUD Karya Maju mendapatkan penghargaan Koperasi Konsumen terbaik Nasional oleh Kementerian Koperasi dan Usaha Kecil Menengah.

Desa Berumbung Baru sebagaimana telah dirubah namanya menjadi "Kampung Berumbung Baru" sesuai dengan Peraturan Daerah Kabupaten Siak Nomor 1 Tahun 2015 Tentang Perubahan Nama Desa Menjadi Kampung di Kabupaten Siak. Salah satu faktor penting keberhasilannya desa/kampung Berumbung Baru dalam melaksanakan pengelolaan desa/kampung secara baik ialah 
terletak dari faktor pemimpinnya yakni Kepala Desa/Kampung Berumbung Baru. Dengan demikian, tujuan penelitian ini ialah 1). Untuk Mengetahui Tipe Kepemimpinan Kepala Desa Dalam Pelaksanaan Kewenangan Lokal Skala Desa di Kampung Berumbung Baru Kecamatan Dayun Kabupaten Siak. 2). Untuk Mengetahui Tipe Kepemimpinan Kepala Desa Dalam Musyawarah Desa di Kampung Berumbung Baru Kecamatan Dayun Kabupaten Siak. 3). Untuk Mengetahui Tipe Kepemimpinan Kepala Desa Dalam Gerakan Usaha Ekonomi Desa di Kampung Berumbung Baru Kecamatan Dayun Kabupaten Siak

Undang - Undang Nomor 6 Tahun 2014 Tentang Desa menyebut desa ialah : "Desa adalah desa dan desa adat atau yang disebut dengan nama lain, selanjutnya disebut Desa, adalah kesatuan masyarakat hukum yang memiliki batas wilayah yang berwenang untuk mengatur dan mengurus urusan pemerintahan, kepentingan masyarakat setempat berdasarkan prakarsa masyarakat, hak asal usul, dan/atau hak tradisional yang diakui dan dihormati dalam sistem Pemerintahan Negara Kesatuan Republik Indonesia”.

Menurut Beratha, Otonomi desa merupakan otonomi yang khas/asli bangsa Indonesia, yang sudah tumbuh dan berkembang dalam kehidupan masyarakat Indonesia seiring dengan perkembangan peradabannya, serta diperoleh secara tradisional atau bersumber dari hukum adat (asli Indonesia), perwujudannya tercermin dalam tata kehidupan masyarakat atau pemerintahan desa adat"'(Beratha,1991:232). Hampir senada dengan Beratha, Zakaria mengemukakan bahwa : "Bila dilihat dengan menggunakan pendekatan teori politik - hukum, otonomi desa identik dengan, atau dapat digolongkan kedalam hak yang bersifat bawaan, yakni hak yang telah tumbuh, berkembang dan terpelihara dalam suatu kelembagaan (institution) yang merupakan urusan rumah tangga sendiri"'(Firmanudin, 2010: 32).

Mengacu kepada pernyataan kedua ahli tersebut, jelas bahwa otonomi desa memang berbeda dengan otonomi daerah. Perbedaannya terutama terletak pada sumber otonominya. Otonomi daerah merupakan distribusi kewenangan dari pemerintah pusat dan diserahkan secara formal berdasarkan peraturan perundang undangan, karena itu otonomi daerah disebut otonomi pemberian, karena merupakan hak yang bersifat pemberian, yakni pemberian atau distribusi kewenangan dari pemerintah pusat. Sedangkan otonomi desa merupakan hak bawaan, yang muncul seiring dengan pertumbuhan dan berkembangnya suatu kesatuan masyarakat desa serta terpelihara menjadi urusan rumah tangga desa itu sendiri.

Otonomi desa di Indonesia mengalami perubahan yang lebih mendasar ialah di undangkannya UU No. 6 tahun 2014 tentang desa yang isinya mengangkat kembali otonomi desa berbasis jati diri desa, mengakomodasi keanekaragaman \& keunikan budaya tiap desa berdasarkan asal-usul dan adat istiadat, didalam sebuah negara kesatuan Republik Indonesia. Maka didalam UU ini dikenal desa adat atau nama lain, dan lembaga adat. Kemudian didalam UU ini bentuk konkrit pemerintah pusat untuk memperkuat otonomi desa ialah dialokasikannya Anggaran Pendapatan Belanja Negara (APBN) untuk pembangunan dan pemberdayaan desa sebesar $10 \%$, yang digunakan untuk mendanai pelaksanaan kewenangan berdasarkan hak asal usul dan kewenangan lokal berskala Desa yang diatur dan 
diurus oleh Desa. adanya pengahasilan tetap, tunjangan, jaminana kesehatan, dan tunjangan lainnya. Dan beberapa perubahan lain yang cukup mendasar dari pengaturan otonomi desa sebelumnya.(Penjelasan UU No.6 Tahun 2014)

Kepala desa sebagai pimpinan satuan organisasi pemerintahan yang mengapalai suatu wilayah pemerintahan mempunyai karakteristik yang berbeda dibandingkan organisasi lainnya. kepala desa dalam kepemimpinannya harus memiliki dua bentuk kepemimpinan yaitu kepemimpinan organisasional serta kepemimpinan sosial. Dengan demikian, kepala desa dalam kepemimpinan organisasional menjadi pimpinan dari satu unit organisasi dengan pengikut yang terdiri dari para bawahan yang patuh karena terikat norma-norma organisasi formal, pada dimensi ini kepala desa berperan sebagai administratif, sehingga kemampuan manajerialnya tampak lebih menonjol dibandingkan kemampuan kepemimpinannya. Sedangkan pada kepemimpinan sosial, hubungan antara pemimpin dengan pengikutnya relatif lebih cair karena jumlah, jenis, dan karakteristik pengikutnya sangat beraneka ragam. Sehingga kepala desa lebih banyak menggunakan kapasitas dan kualitas pribadinya untuk menggerakkan bawahannya, dibandingkan aspek manajerialnya. Maka bentuk kepemimpinan ini, dimensi sosial dan politik lebih dominan dibandingkan dimensi administratif.(Wasistiono,2003:117-118)

Rekrutmen Kepala Desa dalam UU No. 6 Tahun 2014 Tentang Desa dilakukan secara langsung oleh rakyat. Maka dilihat dari tingkatan posisi pemerintahan, Kepala Desa secara teori urutan derajat pentingnya aspek kepemimpinan, ada tiga hal yang perlu dipertimbangkan didalam memilih pimpinan pemerintahan desa (kepala desa) yakni: aspek akseptabilitas, kompatibilitas dan kapabilitas. Aksebtabilitas adalah gambaran tingkat penerimaan pengikut terhadap kehadiran pemimpin. Kompatibilitas, kemampuan untuk menyesuaikan diri dengan kebijakan dari pemerintah tingkat atasnya dan mengakomodasikan kebijakan dari pemerintah tingkat bawahnya maupun tuntutan dari para pengikutnya. Kapabilitas, kemampuan diri si pemimpin baik intelektual maupun moral, yang dapat dilihat dari catatan jejak (track record) pendidikannya maupun jejak sikap dan perilakunya selama ini.(Wasistiono,2003:118-119)

Tipe kepemimpinan kepala Desa dibagi menjadi tiga tipe Kepemimpinan, yakni Kepemimpinan regresif, Kepemimpinan konservatif-involutif dan Kepemimpinan inovatif-progresif.

Kepemimpinan regresif dapat dimaknai sebagai kepemimpinan yang berwatak otokratis, secara teori otokrasi berarti pemerintahan yang kekuasaan politiknya dipegang oleh satu orang. Salah satu cirinya adalah anti perubahan, terkait dengan perubahan tata kelola baru tentang Desa baik itu Musyarawah Desa, usaha ekonomi bersama Desa dan lain-lain sudah pasti akan ditolak. Desa yang parokhial (hidup bersama berdasarkan garis kekerabatan, agama, etnis atau yang lain) serta Desa-Desa korporatis (tunduk pada kebijakan dan regulasi negara) biasanya melahirkan kepemimpinan seperti ini.

Kepemimpinan konservatif-involutif, merupakan model kepemimpinan ini ditandai dengan hadirnya kepala Desa yang bekerja apa adanya (taken for granted), menikmati kekuasaan dan kekayaan, serta tidak berupaya melakukan inovasi (perubahan) yang mengarah pada demokratisasi dan kesejahteraan rakyat. 
Kepemimpinan tipe ini pada umumnya hanya melaksanakan arahan dari atas, melaksanakan fungsi kepala Desa secara tekstual sesuai tugas pokok dan fungsi (tupoksi) kepala Desa.

Kepemimpinan inovatif-progresif, kepemimpinan tipe ini ditandai dengan adanya kesadaran baru mengelola kekuasaan untuk kepentingan masyarakat banyak. Model kepemimpinan ini tidak anti terhadap perubahan, membuka seluasluasnya ruang partisipasi masyarakat, transparan serta akuntabel. Dengan pola kepemimpinan yang demikian kepala Desa tersebut justru akan mendapatkan legitimasi yang lebih besar dari masyarakatnya.

Kepemimpinan Kepala Desa secara garis besar dibagi menjadi 3 (tiga) bagian. Pertama, Kepemimpinan Dalam Pelaksanaan Kewenangan Lokal Skala Desa. Kedua, Kepemimpinan Dalam Musyawarah Desa. Ketiga, Kepemimpinan Dalam Gerakan Usaha Desa.(Mustakim, 2015:11-12)

Konsep kepemimpinan dalam Islam merupakan merupakan hakikat penciptaan manusia. Manusia diciptakan tidak lain ialah sebagai perwakilan Tuhan di muka bumi yang diberi amanah untuk menjaga alam semesta, mengelola dan menggunakan sumber daya untuk kehidupan seluruh ciptannya. Hal tersebut terungkap dalam firman Allah SWT dalam Al-Qur'an Surat Al-Baqarah ayat 30:

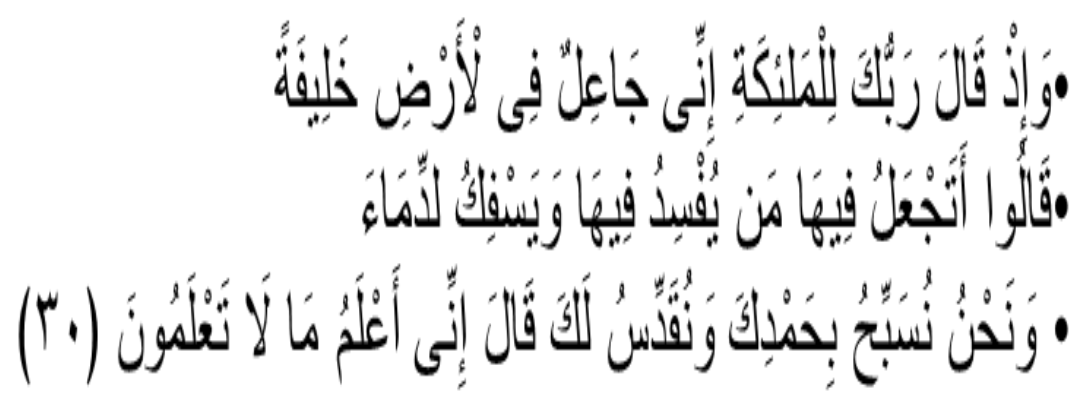

Artinya:"sesungguhnya aku hendak menjadikan seorang khalifah di muka bumi. Mereka berkata mengapa engkau hendak menjadikan (khalifah) di bumi itu orang yang akan membuat kerusakan padanya dan menumpahkan darah, padahal kami senantiasa bertasbih dengan memuji engkau dan mensucikan engkau? Tuhan berfirman: sesungguhnya aku mengetahui apa yang tidak kamu ketahui.

Apapun aktivitas yang dilakukan manusia dalam kehidupannya, baik itu aktivitas di lingkungan keluarga, di lingkungan masyarakat, di organisasi, dan dimanapun. Setiap manusia dimintai pertanggungjawabannya. Terlebih seseorang yang menyelenggarakan negara, pasti setiap waktu melakukan pertanggungjawaban (Akuntabilitas) baik keatas maupun kewabawah. Dan dalam konteks Islam pertanggungjawaban tersebut tidak hanya di dunia saja, namun ada pertanggungjawaban di yaumil akhir, sebagaimana hadist nabi Muhammad SAW:

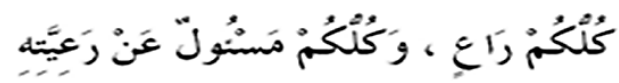

Artinya :Setiap kamu adalah pemimpin, dan setiap pemimpin akan dimintai pertanggungjawaban kepemimpinannya di kemudian hari. (Shahih Bukhari \& Muslim). 
Nabi menggunakan kata ra'in yang berarti gembala untuk pemimpin Ra'in berarti gembala, disini seorang pemimpin berfungsi sebagai pelayan, pembimbing, penuntun dan sekaligus pelindung. Pemimpin sebagai gembala, adalah pemimpin yang fikirannya selalu dipenuhi oleh rasa tanggungjawab, seperti layaknya seorang gembala. Hadis nabi ini, mengajarkan kepada kita bahwa siapa saja yang menjadi pemimpin atau ingin menjadi pemimpin hendaklah ia berfikir dan bertindak seperti layaknya seorang gembala yang baik. Ajaran tentang kepemimpinan dalam Islam ini adalah ajaran tentang tanggungjawab dan resiko, Tanggungjawab seorang pemimpin adalah komitmen dan integritas pribadinya, sementara resiko seorang pemimpin adalah imbalan baik atau buruk yang akan ia terima sebagai konsekuensi logis dari kesediannya memikul tanggungjawab sebagai pemimpin (Alaidin Koto, 2009:9-11).

Nabi Muhammad SAW, selain nabi dan rasul terakhir, sekaligus adalah pemimpin pemerintahan Islam. Nabi Muhammad SAW tokoh yang wajib diteladani Sebagaiman firman Allah SWT dalam Al-Qurean Surat Al-Ahzab ayat 33:

Artinya: "sesungguhnya telah ada pada (diri) Rasulullah itu uswatun hasanah (suri tauladan yang baik) bagimu (yaitu) bagi orang yang mengharap (rahmat) Allah

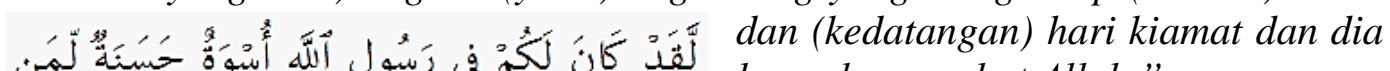
banyak menyebut Allah."

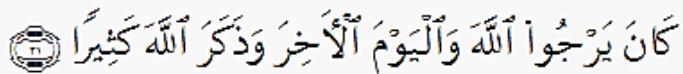

Rasulullah SAW memiliki empat sifat yang dapat dijadikan sebagai teladan oleh pemimpin dalam memimpin masyarakat/rakyat. Keempat sifat itu adalah siddig, amanah, tabligh, dan fathonah.

Siddig artinya jujur/benar. Sifat ini semestinya harus diteladani oleh para pemimpin yang tentunya pantang bagi dirinya untuk berbohong, menipu, menyalahgunakan posisi dan kedudukannya, dan sebagainya. Yang akan ditunjukkan dalam perilakunya adalah mengatakan secara benar apa yang menjadi hak-hak masyarakat yang dipimpinnya.

Amanah artinya dapat dipercaya. Berkaitan dengan sifat amanah ini, seorang pemimpin akan senantiasa menjalankan tugasnya dengan sebaik-sebaiknya. Tidak akan menyalahgunakan kedudukannya untuk kepentingan peribadinya atau keluarganya, namun yang menjadi perhatian utama adalah bagaimana mensejahterakan masyarakat yang dipimpinnya. Dengan demikian, maka sifat amanah dapat disamakan artinya dengan prinsip-prinsip good governance, accountable (akuntabel).

Tabligh artinya menyampaikan. Tabligh juga berarti menyampaikan sesuatu dengan terang dan jelas. Sifat tabligh dapat mendukung terwujudnya prinsip transparency (transparansi, keterbukaan) dalam penyelenggaraan pemerintahan. Sifa tabligh yang dimiliki Rasulullah SAW perlu diteladani para pemimpin denga cara menyampaikan secara terang semua informasi yang berkaitan dengan penyelenggaraan pemerintahan dan pembangunan 
Fathonah artinya, cerdas/bijaksana.Sebagai seorang pemimpin Negara, Rasulullah SAW memperlihatkan kepada umatnya bagaimana seharusnya akhlak seorang pemimpin. Beliau menjadi seorang pemimpin yang memecahkan masalah dengan musyawarah, padahal pandangan beliau sendiri sudah cukup tanpa perlu bermusyawarah denga para sahabat. (disempurnakan dari Hasniati,2008)

Jadi, apabila para pemimpin di semua level pemerintahan, khususnya pemimpin pemerintahan desa sebagai ujung tombak pembangunan Indonesia. Dalam penyelenggaraan pemerintahan meneladani akhlak Rasulullah SAW diatas, maka kita meyakini pembangunan desa di Indonesia, untuk menurunkan angka kemiskinan dan mensejahterakannya akan terwujud, dan menjadikan desa-desa di Indonesia yang maju dan mandiri.

\section{METODE PENELITIAN}

Penelitian ini dilaksanakan di Kampung Berumbung Kecamatan Dayun Kabupaten Siak. Jenis penelitian dalam penelitian ini adalah deskriptif kualitatif.. sumber data primer diperoleh melalui observasi (pengamatan) yang dimulai pada tahap deskripsi yaitu peneliti memasuki situasi sosial (tempat, aktor, aktivitas), kemudian tahap reduksi menentukan fokus memilih diantara yang telah dideskripsikan. Kemudian tahap seleksi yaitu peneliti mengurai fokus menjadi komponen yang lebih rinci, (Sugiyono, 2012:228-230). Data primer juga diperoleh melalui Wawancara mendalam (indepht interview) dengan para narasumber/informan. Dengan menggunakan teknik purposive sampling dan snowball sampling dalam memilih dan menentukan informan/ subjek penelitian. Dan yang menjadi informan dalam penelitian ini ialah Kepala Penghulu Kampung, Perangkat Kampung, Ketua BAPEKAM beserta Anggota Ketua Kelompok Tani Makmur, Direktur BUMDes, Ketua Koperasi dan beberapa tokoh masyarakat. Selanjutnya, sumber data juga diperoleh dari data skunder berupa Rencana Pembangunan Jangka Menengah Kampunng (RPJMKamp), Rencana Kerja Pemerintah Kampung (RKPKam), Peraturan Kampung, Anggaran Pendapatan Belanja Kampung (APBKam), Peraturan Daerah Kabupaten Siak, dan Peraturan Perundang-Undangan yang berhubungan dengan desa.

Data yang terkumpul dianalisis dengan pendekatan analisis data kualitatif model Miles Huberman Interactive Model Of Analysis (Biglen \& Bogdan, 1998) secara sederhana dapat digambarkan

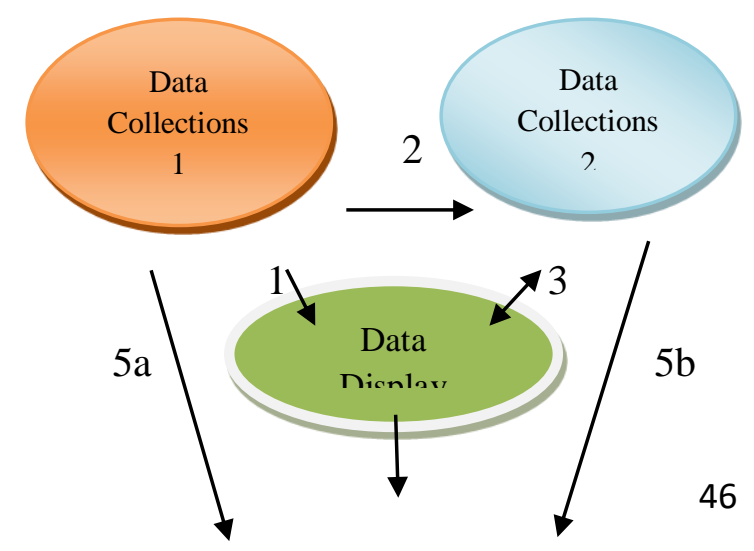




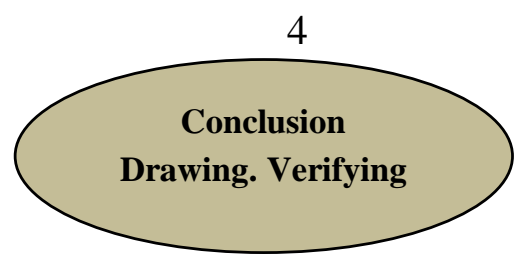

Untuk menguji validitas dan reliabilitas data, digunakan pengujian dengan cara Triangulasi sumber data dan teknik pengumpulan data. (Wiliam Wiersma,1986. dalam Sugiyono,2012:273). Dengan demikian terdapat triangulasi sumber, triangulasi teknik pengumpulan data. Triangulasi sumber data (Kepala Penghulu Kampung, Ketua BAPEKAM, Perangkat Kampung, ketua-ketua lembaga kampung, unsur masyarakat/tokoh masyarakat. sedangkan triangulasi teknik pengumpulan data (observasi, wawancara dan dokumentasi).

\section{HASIL DAN PEMBAHASAN}

Kampung Berumbung Baru merupakan Kampung yang berawal dari bagian Transmigrasi yang berlokasi di Kabupaten Bengkalis pada tahun 1991. Kampung Berumbung Baru terbentuk dari hasil pemekaran Kampung Dayun dibawah Pembinaan Departemen Transmigrasi yang dipimpin oleh KUPT (Kepala Unit Pemukiman Transmigrasi). Dari tahun 1992 sampai 1999 Kampung Berumbung di Pimpin oleh Pejabat Sementara (PJS) Bapak Eddy WP. pada tahun 1999 Kabupaten Siak resmi menjadi daerah otonom baru hasil pemekaran dari Kabupaten Bengkalis. Pada tahun 1999 dilakukan pemilihan kepala desa, dan yang terplih ialah Bapak Jamingan dan memimpin sampai dengan tahun 2007. Pada tahun 2007 sampai tahun 2013 Kampung Berumbung Baru di pimpin oleh Bapak Sunarto yang dipilih melalui Pilkades. Dan Pada tahun 2013 Bapak Sunarto terpilih kembali sebagai penghulu Kampung Berumbung Baru melalui Pilkades, untuk masa jabatan tahun 2013-2019. (Sunarto,2013).

Berdasarkan Undang-Undang Nomor 6 Tahun 2014 Tentang Desa, Pemerintah Kabupaten Siak mengeluarkan Peraturan Daerah Nomor 1 Tahun 2015 Tentang Perubahan Nama Desa menjadi Kampung, dalam ketentuan Peraturan Daerah tersebut, nama Jabatan Kepala Desa juga dirubah menjadi Kepala Penghulu. Sebagai dasar pertimbangan perubaha nama desa menjadi kampung ialah untuk melestarikan kembali nama kampung dimasa lalu. Pada pasal 2 ayat 1-2 Peraturan Daerah Kabupaten Siak Nomor 1 Tahun 2015 menyebutkan Perubahan Penamaan Desa menjadi Kampung bertujuan untuk melestarikan penamaan lama yang pernah digunakan sebelum terbentuknya Kabupaten Siak. Perubahan yang dimaksud ialah dalam rangka menata kembali penamaan dalam bahasa melayu untuk desa dengan sebutan kampung di Kabupaten Siak (Perda Kab.Siak No.1 Tahun 2015)

Desa atau dengan nama lain, dalam spirit lahirnya Undang-Undang Nomor 6 tahun 2014 tentang desa, menegaskan komitmen politik dan konstitusional bahwa negara melindungi dan memberdayakan desa agar menjadi kuat, maju, mandiri, dan demokratis sehingga dapat menciptkan landasan yang kokoh dalam melaksanakan pemerintahan dan pembangunan menuju masyarakat adil, makmur dan sejahtera (Sutoro Eko, 2015:15-16). untuk mencapai tujuan dari lahirnya kebijakan desa 
dalam paradigma yang baru tersebut, dalam implementasinya tidak terlepas dari aspek kepemimpinan (leadership). Kepala desa merupakan pemimpin terdepan dalam mengimplementasikan tujuan Undang-Undang Desa. (Mustakim 2015:12) menyebut aspek paling fundamental dalam menjalankan kepemimpinan Desa adalah Legitimasi, hal ini terkait erat dengan keabsahan, kepercayaan dan hak berkuasa. legitimasi berkaitan dengan sikap masyarakat terhadap kewenangan. Kewenangan untuk memimpin, memerintah, serta menjadi wakil atau representasi dari masyarakatnya.

Pada pasal 19 huruf a dan b Undang -Undang Nomor 6 Tahun 2014 disebutkan desa memiliki kewenangan-kewenangan, antara lain kewenangan berdasarkan hak asal usul dan kewenangan lokal berskala desa. Kewenangan lokal berskala desa mencakup bidang penyelenggaraan pemerintahan, pembangunan, kemasyarakatan, pemberdayaan masyarakat. Berdasarkan pendapat Mustakim 2015:14 menyebutkan tipe kepemimpinan kepala desa yang paling tepat dalam melaksanakan kewenangan lokal berskala desa ialah tipe kepemimpinan yang inovatif-progresif.

Dari hasil analisis penelitian terkait tipe kepemimpinan Kepala Desa/Kampung Berumbung Baru dalam melaksanakan kewenangan lokal berskala desa dapat diuraikan sebagai berikut:

\section{Tipe Kepemimpinan Penghulu Kampung Berumbung Baru Dalam Penyelenggaraan Pemerintahan}

Pemerintahan Desa. Menurut tipe kepemimpinan regresif adalah dirinya sendiri, tidak ada orang lain dan apa yang diucapkan olehnya dianggap keputusan Desa dan harus dipatuhi, Selain itu, kepemimpinan ini sering kali menolak untuk transparan, tidak ada mekanisme pertanggungjawaban kepada publik. Sementara, kepemimpinan konservatif involutif memaknai pemerintahan cenderung Normatif serta prosedural. Menjalankan pemerintahan sesuai prosedur yang ada, dalam hal akuntabilitas tipe kepemimpinan ini hanya membuat dokumen laporan pertanggungjawaban, dalam hal transparansi penyelenggaranan pemerintahan biasanya hanya mengikuti tata tertib yang sudah ada. Sedangkan tipe kepemimpinan inovatif-progresif memaknai pemerintahan Desa sebagai proses menjalankan pemerintahan yang melibatkan partisipasi/prakarsa masyarakat, transparan serta mengedepankan akuntabilitas kinerja. (Mustakim, 2015:14-15)

Dari hasil temuan penelitian, Kepala Penghulu Kampung Berumbung Baru sebagai penyelenggara pemerintahan, telah menjabat selama 2 (dua) periode dalam menyelenggarakan pemerintahan kampung berumbung baru. Bapak Sunarto sebagai Kepala Penghulu Kampung Berumbung Baru dalam menyelenggarakan pemerintahan, berhasil menghantarkan Kampung Berumbung Baru menjadi Kampung yang berprestasi, bahkan mendapatkan juara I terbaik Nasional mewakili Provinsi Riau pada tahun 2015. Dalam penyelenggaraan bidang pemerintahan kampung berumbung baru telah melakukan inovasi dengan menerapkan $E$ Government dalam meningkatkan kualitas pelayanan kepada masyarakat, bentuk inovasi tersebut ialah membangun sistem pelayanan berbasis teknologi informasi dalam bentuk aplikasi yang disebut sebagai Sistem Informasi Manajemen Desa 
(SIMADE). Melalui SIMADE, Pemerintah Kampung Berumbung Baru menyediakan loket pelayanan terpadu untuk lebih memaksimalkan sistem pelayanan terhadap masyarakat, kelengkapan pengarsipan surat-surat dan perangkat Administrasi. Adapun fungsi dari aplikasi Sistem Informasi Manajemen Desa (SIMADE) yang dipergunakan oleh pemerintah Kampung Berumbung Baru adalah:

1. Aplikasi untuk mengolah data penduduk sehingga membantu pemerintah dalam membuat kebijakan yang tepat sasaran.

2. Untuk menyajikan pelayanan prima terhadap masyarakat, dengan target "PELAYANAN SATU MENIT" sehingga perangkat kampung sebagai pelayan masyarakat betul-betul bisa maksimal dan berkualitas.

3. Untuk meningkatkan efisiensi dan efektifitas kerja perangkat Kampung, sehingga akan lebih banyak waktu yang bisa di pergunakan untuk berinteraksi dengan masyarakat.

4. Pendokumentasian surat-surat secara digital akan membantu dalam hal tertib administrasi

Selain dari aplikasi Sistem Informasi Manajemen Desa (SIMADE), Pemerintah Kampung Berumbung Baru pada tahun 2014 juga telah membuat aplikasi Sistem Informasi Anggaran Desa (SIAD), aplikasi SIAD dalam keterangan Kepala Penghulu (Sunarto) menyebutkan; SIAD berfungsi sebagai aplikasi untuk memudahkan desa/kampung berumbung baru dalam hal pengelolaan keuangan kampung, tertib penyusunan Anggaran Pendapatan Dan Belanja Desa (APBDes), pembuatan Surat Pertanggung Jawaban (SPJ) kegiatan kampung.

Untuk melakukan penyebaran informasi pembangunan kampung, Pemerintah Kampung Berumbung Baru membuat website dan baliho. Melalui website tersebut informasi Anggaran Pendapatan Belanja Kampung dapat diketahui oleh masyarakat secara luas. Anggaran Pendapatan Belanja (APB) Kampung Berumbung Baru. Dalam keterangan kepala Kampung (Sunarto) sebagai Kepala Penghulu Kampung menyebutkan bahwa:

"website desa dibuat agar penyelenggaraan pemerintahan Kampung sebagai ujung tombak pelayanan pemerintahan ikut serta dalam perkembangan era globalisasi, website berfungsi sebagai wadah menginformasikan potensi Kampung, agar dengan mudah akan diketahui oleh dunia luar, dengan potensi kampung yang ada dan diketahui oleh dunia luar akan bisa mendatangkan atau menarik minat para investor untuk melakukan investasi di Kampung Berumbung Baru, sehingga akan mendorong terwujudnya Kampung yang mandiri. Dengan adanya website kampung, sebagai sarana untuk saling berbagi dengan pihak manapun sehingga Kampung semakin bisa mengembangkan diri dengan segala potensi yang ada".

Data lainnya yang menunjukkan kepemimpinan Kepala Penghulu Kampung Berumbung Baru yang inovatif-progresif ialah Pemerintah Kampung Berumbung Baru juga berhasil membangun partisipasi masyarakat Kampung Berumbung Baru yang begitu tinggi, hal tersebut terbukti dari jumlah swadaya masyarakat dalam kegiatan fisik tahun 2013 sebesar Rp. 773.841.946. untuk tahun 2014 sebesar Rp. 
896.917.763. sedangkan bentuk swadaya non fisik apabila dinilai dalam bentuk uang pada tahun 2013 sebesar Rp. 2.790.685.600. untuk tahun 2014 sebesar Rp. 2.814.368.400. (Sunarto, 2015). Partisipasi masyarakat Kampung Berumbung Baru dalam bentuk swadaya, menunjukkan Penyelenggaraan Pemerintahan Kampung Berumbung Baru dijalankan dengan prinsip-prinsip Good Governance, dengan terjalinnya relasi antara pemerintah dan masyarakat.

Data lain yang menunjukkan pengaruh kepemimpinan Kepala Penghulu Kampung Berumbung Baru yang Inovatif-Progresif dalam penyelenggaraan pemerintahan ialah pelayanan dalam bidang kesehatan, pada Kampung Berumbung Baru Kepala Penghulu Kampung bersama masyarakat membuat program “Kampung Siaga" Berumbung Baru, yang berdiri pada tahun 2007, sebagai bentuk kemandirian Kampung dalam bidang kesehatan, dan untuk mengoperasionalkan progra "Kampung Siaga " ini murni berasal dari swadaya masyarakat yang bersumber dari iuran bulanan masyarakat. Sejak berdirinya program "Kampung Siaga" dana yang terkumpul untuk program "Kampung Siaga" per 30 April 2015 sebesar Rp 253.522.000,- yang murni swadaya masyarakat dan yang telah tersalurkan sebesar Rp 245.522.000,-. Dengan saldo akhir sebesar Rp 8.000.000,-. Kampung Siaga Berumbung Baru telah mendapat bantuan ambulan dari Dinas Kesehatan Kabupaten Siak. (Sunarto, 2015).

Dari data-data temuan penelitian, dapa disimpulkan bahwa Kepala Penghulu Kampung Berumbung (Sunarto), dalam melaksanakan kewenangan lokal berskala desa di bidang penyelenggaraan pemerintahan, dapat dikatakan berhasil karena Kepala Penghulu Kampung membuka ruang seluas-luasnya kepada masyarakat untuk terlibat dalam menjalankan roda pemerintahan, setiap keputusankeputusan yang diambil selalu melibatkan banyak pihak. Selain itu, kepala penghulu kampung dalam menyelenggarakan pemerintahan tidak hanya sekedar mengikuti prosedur-prosedur tata pemerintahan secara normatif, atau sekedar mengikuti petunjuk teknis pengelolaan desa/kampung, atau bahasa lainnya yang penting anggaran desa sudah dijalankan, dan terealisasi dalam satu tahun anggaran, dan dilaporkan pertanggungjawabannya. Dengan demikian, kepala penghulu kampung berumbung baru telah melangkah lebih maju dalam menjalankan roda pemerintahan desa/kampung dengan menerapkan tipe kepemimpinan yang inovatif-progresif yaitu memaknai pemerintahan Desa sebagai proses menjalankan pemerintahan yang melibatkan partisipasi/prakarsa masyarakat, transparan serta mengedepankan akuntabilitas kinerja.

\section{Tipe Kepemimpinan Penghulu Kampung Berumbung Baru Dalam Pembangunan Kampung}

Rangkaian kegiatan pembangunan Desa terdiri dari perencanaan, pelaksanaan, dan pengawasan kegiatan. Pada kepemimpinan regresif pembangunan Desa harus sesuai dengan kemauannya, program pembangunan diarahkan untuk kesejahteraan dirinya sendiri. Sementara kepemimpinan konservatifinvolutif akan melaksanakan pembangunan Desa sesuai mekanisme perencanaan pembangunan yang sudah ada dan yang penting baginya terdapat dokumen perencanaan Program 
pembangunan. Sedangkan kepemimpinan inovatif-progresif, pembangunan Desa dilaksanakan dengan melibatkan partisipasi masyarakat mulai dari merencanakan, melaksanakan serta mengawasi proyek pembangunan. (Mustakim, 2015:15)

Perencanaan pembangunan desa adalah proses tahapan kegiatan yang diselenggarakan oleh pemerintah Desa dengan melibatkan Badan Permusyawaratan Desa dan unsur masyarakat guna pemanfaatan dan pengalokasian sumber daya desa dalam rangka mencapai tujuan pembangunan desa.(Wahyudin Kessa,2015:18) Perencanaan Pembangunan Kampung Berumbung Baru dimulai dengan penyusunan Rencana Pembangunan Jangka Menengah Kampung (RPJMK) untuk jangka waktu 6 tahun. Selanjutnya penyusunan Rencana Pembangunan Tahunan Kampung (RPTK) atau yang disebut Rencana Kerja Pemerintah Kampung (RKPKamp) yang merupakan penjabaran dari RPJMK untuk jangka waktu 1 tahun yang kemudian ditetapkan dengan peraturan desa.

Dari hasil temuan penelitian, ditemukan perencanaan kebijakan pembangunan Kampung Berumbung Baru telah mengikut sertakan unsur masyarakat dalam setiap tahap penyusunan RPJMK dan RKP Kampung. proses penyusunannya dilakukan dengan partispatif. Menurut (Loekman,1995:15) pentingnya partisipasi masyarakat dalam pelembagaan sistem pembangunan yaitu, adanya kerjasama antara rakyat dan pemerintah dalam merencanakan, melaksanakan, dan membiayai pembangunan. Dalam Peraturan Menteri Dalam Neri No. 114 tahun 2014, tentang Pedoman Pembanguna Desa, disebutkan bahwa Pembangunan Partisipatif adalah suatu sistem pengelolaan pembangunan di desa dan kawasan perdesaan yang dikoordinasikan oleh kepala Desa dengan mengedepankan kebersamaan, kekeluargaan, dan kegotongroyongan guna mewujudkan pengarusutamaan perdamaian dan keadilan sosial.(Permendagri, No.114 Tahun 2014).

Pada tahap pelaksanaan pembangunan di Kampung Berumbung Baru dari hasil temuan penelitian menunjukkan bahwa partisipasi masyarakat dalam pelaksanaan kegiatan Pembangunan Kampung Berumbung Baru dilakukan dengan melewati beberapa tahapan. Pertama, tahapan persiapan pelaksanaan kegiatan yang terdiri dari penetapan pelaksana kegiatan, penyusunan rencana kerja, sosialisasi kegiatan, pembekalan pelaksana kegiatan, penyiapan dokumen administrasi, pengadaan tenaga kerja dan pengadaan bahan/material. Kedua, Tahapan pelaksanaan kegiatan yang terdiri dari rapat kerja dengan pelaksana kegiatan, pemeriksaan pelaksanaan kegiatan infrastruktur Kampung, perubahan pelaksanaan kegiatan, pengelolaan pengaduan dan penyelesaian masalah, penyusunan laporan hasil pelaksanaan kegiatan, musyawarah pelaksanaan kegiatan Kampung dalam rangka pertanggungjawaban hasil pelaksanaan kegiatan dan pelestarian dan pemanfaatan hasil kegiatan.

Tahap pemantauan dan pengawasan pembangunan Kampung. Masyarakat Kampung berhak melakukan pemantauan terhadap pelaksanaan Pembangunan Kampung. (Wahyudin Kessa,2015:65). Dari hasil temuan penelitian menunjukkan bahwa Masyarakat Kampung Berumbung Baru selalu diminta oleh Kepala Penghulu Kampung untuk memberikan saran dan masukan terkait dengan proses perencanaan pembangunan, pelaksanaan kegiatan pembangunan dan bahkan dalam 
hal ini Pemerintah Kampung Berumbung Baru pada setiap bulannya melakukan kegiatan rutin berupa rapat koordinasi dengan unsur Pemerintahan Kampung, Ketua RT/RW, Kepala Dusun ketua-ketua lembaga Kampung dengan melibatkan tokoh-tokoh masyarakat dari setiap RT/RW, Dusun, dalam rangka menerima masukan dan koordinasi pelaksanaan kegiatan pembangunan Kampung yang sedang berjalan maupun yang telah selesai dilaksanakan”.

Pembangunan Desa, akan sangat berhubungan dengan aspek kepemimpinan Kepala Desa, sebagai agen penggerak pembangunan itu sendiri. Pada Tipe kepemimpinan regresif. Pembangunan desa dilakukan oleh kepala desa harus sesuai dengan kemauannya, program pembangunan diarahkan untuk kesejahteraan dirinya sendiri. Tipe Kepemimpinan Konservatif-Involutif Kepala Desa akan melaksanakan pembangunan Desa sesuai mekanisme perencanaan pembangunan yang sudah ada dan yang penting baginya terdapat dokumen perencanaan program pembangunan. Sedangkan pada tipe kepemimpinan inovatif-progresif, pembangunan Desa dilaksanakan dengan melibatkan partisipasi masyarakat mulai dari merencanakan, melaksanakan serta mengawasi proyek pembangunan.(Mustakim, 2015:15).

Kepala Penghulu Kampung Berumbung Baru memberikan pengaruh besar dalam mendorong partisipasi masyarakat dalam semua proses tahapan pembangunan Kampung. Kepala Penghulu Kampung Berumbung Baru menerapkan Tipe Kepemimpinan Inovatif-Progresif sehingga mendapat kepercayaan (trust) dan dukungan (support) dari masyarakat Kampung dalam mewujudkan program-program pembangunan Kampung.

\section{Tipe Kepemimpinan Penghulu Kampung Berumbung Baru Dalam Kemasyarakatan Desa}

Pembinaan Kemasyarakatan Desa sebagai bagian dari kewenangan lokal berskala Desa dalam hal ini adalah pelaksanaan tanggung jawab Desa dalam memelihara ketentraman dan ketertiban.

Pada kepemimpinan regresif, untuk menjaga ketentraman dan ketertiban Desa ditanggani oleh dirinya sendiri, pemimpin ini akan mengontrol kehidupan masyarakat Desa, bila terdapat masyarakat yang dianggap meresahkan dirinya sendiri akan ditindak, diintimidasi. Tipe kepemimpinan konservatif-involutif dalam hal menjaga ketenteraman dan ketertiban di Desa secara prosedural akan dilaksanakan dengan cara koordinasi dengan kepolisian maupun Babinsa. Sedangkan pada tipe kepemimpinan inovatif-progresif akan melibatkan seluruh nsur masyarakat termasuk untuk bersama-sama menjaga ketentraman dan ketertiban Desa .(Mustakim, 2015:16).

Dari temuan peneliti, untuk mewujudkan keamanan dan ketertiban dilaksanakan pembinaan kepada warga masyarakat untuk melaksanakan Siskamling/Ronda. Kegiatan bertempat dipos jaga yang tersedia dilingkungan masing-masing. Kegiatan ini dipantau langsung oleh Polisi Kampung atau BABINKAMTIBMAS yang telah juga memiliki gedung yang dibangun melalui dana POKMAS Pemerintahan Kabupaten Siak. Kegiatan ini juga langsung dikordinasi oleh Ketua RT dan LINMAS dilingkungan masing-masing. Kegiatankegiatan yang telah dilaksanakan oleh pelaksanaan bidang keamanan dan ketertiban 
ialah secara rutin mengadakan kegiatan monitoring ke tiap Pos Kamling, dan melaporkan kepada pihak kepolisian setiap kejadian yang bersifat pelanggaran hukum di wilayah Kampung Berumbung Baru.

Dari data tersebut, menunjukkan bahwa keterlibatan semua unsur di Kampung Berumbung Baru, menunjukkan Tipe Kepemimpinan Kepala Kampung Berumbung Baru (Sunarto) yang inovatif-progresif, dengan kemampuannya menggerakkan seluruh komponen untuk menjaga kemanan dan ketertiban Kampung.

\section{Tipe Kepemimpinan Penghulu Kampung Berumbung Baru Dalam Pemberdayaan Masyarakat Desa}

Pemberdayaan Masyarakat Desa adalah upaya mengembangkan kemandirian dan kesejahteraan masyarakat dengan meningkatkan pengetahuan, sikap, keterampilan, perilaku, kemampuan, kesadaran, serta memanfaatkan sumber daya melalui penetapan kebijakan, program, kegiatan, dan pendampingan yang sesuai dengan esensi masalah dan prioritas kebutuhan masyarakat Desa. (Permendes PDT Dan Transmigrasi, No.3 Tahun 2015).

Tipe kepemimpinan regresif biasanya menolak untuk mendampingi masyarakat Desa, masyarakat yang berdaya dianggap mengancam posisinya. Kepemimpinan. Tipe konservatif-involutif hanya akan memberdayakan keluarga, kerabat atau warga masyarakat yang dapat dikendalikan olehnya. Sedangkan kepemimpinan inovatif-progresif akan melakukan pemberdayaan Desa dengan memunculkan prakarsa masyarakat, selain itu tipe kepemimpinan ini akan melakukan kaderisasi dan menyiapkan kader-kader Desa serta membuka akses untuk peningkatan kapasitas masyarakat Desa. (Mustakim, 2015:16).

Hasil penelitian mengenai Pemberdayaan Masyarakat di Kampung Berumbung Baru ialah pada bidang pembangunan, pemanfaatan dan pemeliharaan infrasruktur dan lingkungan Desa antara lain: Infrastruktur Jalan Pemukiman Kampung, Pembangkit Listrik Tenaga Diesel Kampung, Sarana dan Prasarana Kesehatan Kampung Berumbung Baru, Air Bersih, Sarana dan Prasarana Pendidikan Kampung Berumbung Baru, Pasar dan BUMKam Kampung Berumbung Baru, Koperasi Unit Desa, Waserda, KUD Sumber Rezeki Kampung Berumbung Baru. Peternakan Sapi Dan Kambing, Peternakan Ayam dan Ikan Kampung, Pembuat Pupuk Limbah dari Kotoran Sapi.

Pengelolaan pasar desa, Bumkam, KUD, kelompok tani di Kampung Berumbung Baru yang telah terorganisasi dengan baik merupakan proses kaderisasi yang dilakukan oleh Kepala Penghulu Kampung Berumbung Baru, dan hal ini bermakna bahwa tipe kepemimpinan yang inovatif-progresif dari kepala penghulu kampung, mampu menggerakkan potensi kampung yang ada, baik sumberdaya manusia dan sumber daya alam.

\section{Tipe Kepemimpinan Kepala Kampung Berumbung Baru dalam Musyawarah Kampung}


UU Nomor 6 Tahun 2014 tentang Desa menyatakan Musyawarah Desa merupakan forum permusyawaratan yang diikuti oleh Badan Permusyawaratan Desa, Pemerintah Desa, dan unsur masyarakat Desa untuk memusyawarahkan hal yang bersifat strategis dalam penyelenggaraan Pemerintahan Desa.

Permen Desa PDTT Nomor 2 Tahun 2015 tersebut juga menyaratkan penyelenggaraan Musyawarah Desa dilaksanakan secara partisipatif, demokratis, transparan dan akuntabel dengan berdasarkan kepada hak dan kewajiban masyarakat. (Permendes PDT Dan Transmigrasi, No.2 Tahun 2015).

Partisipatif. Musyawarah Desa yang diharapkan sebagaimana amanat UU Desa adalah adanya pelibatan masyarakat secara keseluruhan, bagi pemimpin dengan tipe kepemimpinan regresif partisipasi masyarakat dalam Musdes tidak diharapkan, bahkan pemimpin tipe ini cenderung menolak menyelenggarakan Musyawarah Desa. Kepemimpinan konservatif-involutif akan melaksanakan Musyawarah Desa sesuai tata tertib atau aturan yang ada, daftar peserta akan diseleksi terlebih dahulu dipilih dari sekian calon peserta Musdes yang dapat masyarakat, tokoh agama, tokok masyarakat, perwakilan perempua, hingga perwakilan masyarakat miskin dalam Musyawarah Desa. dikendalikannya. Sedangkan kepemimpinan inovatif-progresif dalam peleksanaan Musdes akan melibatkan setiap unsur. (Mustakim, 2015:18).

Demokratis. Setiap orang dijamin kebebasan berpendapat serta mendapatkan perlakuan yang sama dalam forum Musdes. Pada kepemimpinan regresif biasanya tidak mengingginkan pendapat, masukan dari orang lain bila ada masyarakat yang kritis cenderung akan di intimidasi. Kepemimpinan konservatifinvolutif, cenderung akan melakukan seleksi siapa yang diinginkan pendapatnya, masukan terutama dari atasan akan lebih diperhatikan, dalam forum Musdes pendapat atau masukan cenderung di setting atau diatur terlebih dahulu agar dapat menguntungkan dirinya. Pada kepemimpinan inovatif-progresif, Setiap orang akan dijamin kebebasan berpendapatnya dan mendapatkan perlakuan yang sama, serta akan melindunginya dari ancaman dan intimidasi (Mustakim, 2015:9).

Transparan. Peserta Musdes mendapatkan informasi secara lengkap dan benar perihal hal-hal bersifat strategis yang akan dibahas. Pada kepemimpinan regresif cenderung menolak untuk transparan, tidak akan memberikan informasi apapun kepada masyarakatnya meskipun menyangkut kepentingan masyarakatnya sendiri. Sedangkan kepemimpinan konservatif-involutif, transparansi akan dilakukan terbatas, informasi hanya diberikan kepada pengikut atau pendukungnya saja. Tipe kepemimpinan inovatif-progresif akan membuka akses seluas-luasnya kepada masyarakatnya, semakin luas serta lengkap informasi yang disampaikan kepada masyarakat dianggap akan dekat dengan kesuksesan program Desa (Mustakim, 2015:19).

Akuntabel, Hasil -hasil Musdes berikut tindaklanjutnya harus dipertanggungjawabkan kepada masyarakat Desa. Kepemimpinan regresif cenderung tidak akan menyampaikan keputusan musyawarah Desa, termasuk menolak mempertanggungjawabkan kinerjanya kepada masyarakat. Pada kepemimpinan konservatif-involutif, Hasil musyawarah Desa maupun tindak lanjutnya hanya akan disampaikan kepada pengikutnya saja. Sedangkan kepemimpinan inovatif-progresif, Hasil Musyawarah Desa serta tindak lanjut 
keputusan musyawarah akan disampaikan kepada masyarakat dan dilakukan setiap saat (Mustakim, 2015:20).

Hasil penelitian, Kepala Penghulu Kampung menerapkan Kepemimpinan inovatif-progresif dalam proses pengambilan keputusan dalam musyarawarah kampung, dapat terlihat dari adanya kegiatan Rapat Koordinasi Pemerintahan Kampung yang diikuti BAPEKAM, Perangkat Kampung, LPM, RT, RK, LINMAS dan BHABINKAMTIBMAS dan perwakilan tokoh mayarakat, tokoh agama, tokoh pemuda dan tokoh perempuan. Kemudian, adanya Rapat koordinasi tingkat Dusun yang dikuti RT, RK, Kelompok Tani, Perangkat Kampung dan BAPEKAM yang ada didalam Dusun tersebut, serta perwakilan masyarakat pada setiap Dusun dan $\mathrm{RT} / \mathrm{RK}$.

Kepala Penghulu Kampung, membuka seluas-luasnya ruang partisipasi masyarakat, transparan serta akuntabel, hal teresebut dapat diketahui dari proses penyusunan perencanaan kebijakan pelaksanaan, dan pengawasan yang diberikan oleh masyarakat untuk mengevaluasi pelaksanaan kegiatan pembangunan yang sedang berjalan maupun yan telah selesai di laksanakan, melalui sarana musyawarah/rapat-rapat Kampung yang dilaksanakan dengan melibatkan komponen masyarakat dan unsur aparatur Kampung.

\section{Tipe Kepemimpinan Kepala Kampung Berumbung Baru Dalam Usaha Gerakan Ekonomi Desa}

Kegagalan Desa menggerakkan usaha ekonomi Desa adalah aspek kepemimpinan Desa. Kepala Desa sebagai pemimpin Desa tidak mempunyai imajinasi dan prakarsa yang kuat untuk menggerakkan masyarakat dan mengonsolidasikan aset ekonomi lokal. Kepala Desa ataupun Pemerintah Desa hanya disibukkan dengan mengelola bantuan dari pemerintah baik itu pusat, provinsi maupun Kabupaten Kota. Dan Seringkali bantuan yang diberikan tersebut masih belum menyentuh gerakan ekonomi lokal. (Mustakim, 2015:20).Kepemimpinan di Desa dalam pengembangan Usaha Ekonomi Desa, terutama berkaiatan dengan pemanfaatan aset Desa yang dimiliki oleh Desa dan pendirian serta pemanfaatan BUM Desa.

Dalam pengelolaan aset desa. pada tipe kepemimpinan regresif aset Desa atau potensi sumberdaya lokal cenderung akan dikuasi secara pribadi. Sedangkan kepemimpinan konservatif-involutif, Aset Desa akan dikuasai dan dimanfaatkan untuk kesejahteraan dirinya dan kelompoknya saja. Pada kepemimpinan inovatifprogresif, akan melibatkan prakarsa masyarakat Aset Desa direvitalisasi dan dimanfaatkan seluas-luasnya untuk kesejahteraan masyarakatnya. Adanya inovasi baru untuk menambah aset Desa(Mustakim, 2015:23).

Dalam pengelolaan BUM Desa. Kepemimpinan regresif , keberadaan BUM Desa akan dikontrol penuh, setiap usaha ekonomi akan diarahkan untuk kepentingan pribadinya. Sedangkan kepemimpinan konservatif-involutif, BUM Desa hanya akan diisi oleh kelompoknya saja, arah program pengembangan ekonomi Desa cenderung meminta arahan dari pemerintah kabupaten/kota. Sementara itu kepemimpinan inovatif-progresif, BUM Desa didirikan dengan prakarsa masyarakat, apa yang menjadi rencana usaha, penentuan personil, aturan 
main akan dibahas bersama-sama secara demokratis melalui Musyawarah Desa (Mustakim, 2015:24).

Dari hasil penelitian diperoleh keterangan bahwa, Pemerintah Kampung Berumbung Baru memiliki aset desa berupa tanah kas seluas 10 Hektar yang dikelola oleh masyarakat dan menjadi salah satu sumber Pendapatan Asli Kampung. Pendapatan Asli Kampung tersebut telah digunakan untuk membangun infrastruktur (jalan desa, drainase), tempat ibadah dan bantuan sosial.

Badan Usaha Milik Kampung yang didirikan, dengan modal awal sebesar Rp. 500.000.000,- mengelola unit usaha keuangan simpan pinjam (financial business). Setelah berjalan selama 5 (lima) tahun, Badan Usaha Milik Kampung Sumber Rezeki Kampung Berumbung Baru pada saat ini telah memiliki aset sebesar Rp 3.446.000.000,- dengan bidang usaha unit usaha simpan pinjam, unit usaha Pasar kampung. Kemudian, BUMKam Sumber Rezeki juga memberikan pelayanan sosial berupa penerimaan tabungan haji, Replanting, Qur'ban dan lainlain. BUMKam juga memiliki usaha perdagangan (trading) dalam bentuk kredit peralatan elektronik dan perabot rumah tangga.

Dari data tersebut, dapat dikatakan bahwa tipe kepemimpinan Kepala Kampung Berumbung Baru dalam usaha gerakan ekonomi desa, menerapkan kepemimpinan inovatif-progresif.

\section{KESIMPULAN DAN SARAN}

\section{Kesimpulan}

Pengelolaan Desa/Kampung terdiri dari penyelenggaraan pemerintahan, pelaksanaan pembangunan, pembinaan kemasyarakatan dan pemberdayaan masyarakat. Hasil penelitian dapat disimpulkan bahwa kepemimpinan Kampung Berumbung Baru dalam pengelolaan Kampung dapat dikatakan berhasil, dengan tipe Kepemimpinan Kepala Penghulu Kampung yang inovatif-progresif yang diterapkan, baik dalam kepemimpinan pelaksanaan kewenangan lokal berskala desa, kepemimpinan dalam musyawarah kampung sebagai mekanisme dalam pengambilan keputusan, dimana dalam musyawarah-musyawarah yang dilaksanakan mengedepankan aspek partisipasi masyarakat, demokratis, transparansi dan akuntabilitas. Begitu juga halnya, dengan Kepemimpinan Kepala Penghulu Kampung Berumbung Baru dalam usaha gerakan ekonomi kampung dalam pengelolaan aset-aset kampung, pendirian dan pengelolaan Badan Usaha Milik Kampung.

\section{Saran}

Berdasarkan hasil penelitian yang telah dibahas pada bab sebelumnya maka peneliti menayarankan hal-hal sebagai berikut :

1. Kepemimpinan yang inovatif-progresif dalam pengelolaan Kampung Berumbung Baru, hendaknya dipertahankan oleh siapapun yang akan memimpin kampung berumbung baru kedepannya.

2. Dalam usaha gerakan ekonomi kampung, khususnya mengenai pengembangan Unit-Unit Badan Usaha Milik kampung (BUMKam), hendaknya Kepala Penghulu Kampung dan Pengelola BUMKam untuk dapat menginventarisasi 
potensi-potensi kampung yang dapat dikembangkan menjadi unit usaha pada BUMKam.

\section{REFERENSI}

Al-Qur'an dan Terjemahnya, 1995. Surat Al-Baqarah ayat 30. Departemen Agama Republik Indonesia. Jakarta , 1995. Surat Al-Ahzab ayat 33. Departemen Agama Republik Indonesia. Jakarta

Beratha, I Nyoman. 1991. Pembangunan Desa Berwawasan Lingkungan, Jakarta : Bumi Aksara.

Biglen \& Bogdan, 1998. Qualitative research Methodology. New York: Harper and Row

Eko Sutoro, 2015. Regulasi Baru, Desa Baru Ide, Misi, dan Semangat UU Desa, Jakarta: Kementerian Desa Pembangunan Daerah Tertinggal, Dan transmigrasi Republik Indonesia.

Firmanudin Agus. 2005. Tesis "Kajian Tentang Implementasi Kebijakan Otonomi Desa Berdasarkan Undang Undang Nomor 22 Tahun 1999 Ditinjau Dari Aspek Kelembagaan Dan Pembiayaan Pemerintahan Desa Di Kecamatan Cipari Kabupaten Cilacap”. Pascasarjana Program Studi Ilmu Administrasi Publik Universitas Jenderal Soedirman Purwokerto.

Hasniati, 2008, Sikap Dan Prilaku Birokrat Garis-Depan Dalam Pelayanan Publik Ditinjau Dari Perspektif Syariat Islam. Artikel Al-Fikr Volume 17 Nomor 1 Tahun 2013.

Koto Alaiddin, 2009: Islam, Indonesia dan Kepemimpinan Nasional : Refleksi Pemikiran Tentang Realitas Sosial Politik di Indonesia, Ciputat Press, Jakarta.

Loekman, Soetrisno. 1995. Negara dan Peranannya Dalam Menciptakan Pembangunan Desa yang Mandiri. Dalam Seminar Strategi Pembangunan Pedesaan, Yogyakarta: UGM-UNWAMA. 1-3 Oktober 1987.

Mustakim Mochammad Zain, 2015. Buku 2 Kepemimpinan Desa, Kementerian Desa, Pembangunan Daerah Tertinggal, Dan Transmigrasi Republik Indonesia Jakarta.

Silahuddin, M. 2015. Buku 1 Kewenangan Desa dan Regulasi Desa, Kementerian Desa, Pembangunan Daerah Tertinggal, Dan Transmigrasi Republik Indonesia Jakarta.

Sadu Wasistiono, 2003. Kapita Selekta Manajemen Pemerintahan Daerah. Bandung: Fokusmedia

Sugiyono, 2012. Metode Penelitian Kuantitatif, Kualitatif dan RD. Bandung, Alfabeta.

Sunarto, 2013. Profil Kampung Berumbung Baru. Pemerintah Kampung Berumbung Baru.

Sunarto, 2015. Ekspos Kampung Berumbung Baru Pada Acara Lomba Desa Tingkat Provinsi Riau.

Wahyudin Kessa, 2015. Buku 6 Perencanaan Pembangunan Desa, Jakarta: Kementerian Desa Pembangunan Daerah Tertinggal, Dan transmigrasi Republik Indonesia.

\section{Peraturan Perundang-Undangan :}


Undang - Undang Republik Indonesia Nomor 6 Tahun 2014 Tentang Desa. 15 Januari 2014. Lembaran Negara Republik Indonesia Tahun 2014 Nomor 7. Jakarta.

Peraturan Menteri Desa, Pembangunan Daerah Tertinggal, dan Transmigrasi Republik Indonesi Nomor 1 Tahun 2015 Tentang Pedoman Kewenangan Berdasarkan Hak Asal Usul dan Kewenangan Lokal Berskala Desa.

Peraturan Menteri Dalam Negeri Republik Indonesia Nomor 114 Tahun 2014 Tentang Pedoman Pembangunan Desa

Peraturan Menteri Desa Pembangunan Daerah Tertinggal, Dan Transmigrasi Republik Indonesia Nomor 3 Tahun 2015 Tentang Pendamping Desa

Peraturan Menteri Desa Pembangunan Daerah Tertinggal, Dan Transmigrasi Republik Indonesia Nomor 2 Tahun 2015 Tentang Pedoman Tata Tertib dan Mekanisme Pengambilan Keputusan Musyawarah Desa

Peraturan Daerah Kabupaten Siak Nomor 1 Tahun 2015 Tentang Perubahan Internet:

Penamaan Desa Menjadi Kampung

Sabrina Rizkita. http://kedesa.id/id_id/desa-berumbung-baru-desa-unggulan-diranah-riau/ diakses tanggal 10 maret 2017 pukul 16.00 WIB

Dinas Komunikasi, Informatika, Dan Statistik Provinsi Riau. 16 Desember 2015, diakses tanggal 10 Maret 2017 Pukul 16.00 WIB 